\title{
In Vitro demonstration of Pseudomonas Growth and Phenotypic Examinations of the Cells Under Cold Shock
}

\author{
Anika Bushra Moumita ${ }^{1}$, Nafisa Tabassum¹, Ifra Tun Nur ${ }^{*}$ \\ ${ }^{1}$ Department of Microbiology, Stamford University Bangladesh, 51 Siddeswari Road, Dhaka 1217, Bangladesh.
}

\begin{abstract}
The present study attempted to detect the effect of cold shock on Pseudomonas aeruginosa, $P$. fluorescence, and $P$. putida; to deduce the culturable cells, the possible dead cells and viable but non-culturable (VBNC) cells; i. e., living but not capable of forming the colony forming units (CFUs) at $0^{\circ} \mathrm{C}$ and at $4^{\circ} \mathrm{C}$. Estimation of $\mathrm{VBNC}$ at low temperature was performed by deducting the number of culturable cells (formed as $\mathrm{CFUs}$ ) at $0^{\circ} \mathrm{C}$ and at $4{ }^{\circ} \mathrm{C}$ from the culturable cells at $37^{\circ} \mathrm{C}$. Maximum culturable cells (around $10^{6} \mathrm{CFU} / \mathrm{ml}$ ) appeared at 24-48 hours, and after that, a gradual decline in the numbers of the culturable cells was observed. A minor but significant growth reduction was noticed in Minimal Broth compared to that in Luria Broth. Significant reduction in the culturable cells of all three strains was noticed under cold shock. However, a fraction of the population of each strain was observed to survive under cold stress. Interestingly while the number of culturable cells decreased in course of time under cold shock, the number of VBNC apparently seemed to be constant or to be increased. A comparatively lower number of VBNC was noticed under cold shock in case of $P$. putida which in turn affected culturability at ambient temperature.
\end{abstract}

Key words: Pseudomonas aeruginosa; $P$. fluorescence; $P$. putida; cold shock; culturable cells, viable but non-culturable (VBNC) cells.

\section{Introduction}

Years after years biologists have drawn their interests on bacterial growth to especially detecting the growth kinetics, bacterial generation time, survival and culturability (along with the determination of viable but non-culturable (VBNC) cells under various conditions like in nutrient limiting situation or certain exogenous or endogenous stresses ${ }^{1-3}$. Many bacterial species have been noticed to undergo the VBNC state, which is indeed a sort of survival strategy when exposed to heat shock or the oxidative stress ${ }^{4-7}$.A wide range of bacteria are known to activate different transcriptional regulatory network (TRN) at the stationary phase, improving the potential of stress defensive response ${ }^{8-10}$ against various stress transmitting stimuli; i.e., heat shock, pressure, irradiation, $\mathrm{pH}$, osmolite/salt concentration, elevated level of reactive oxygen species (ROS), imbalance in redox-state and toxic chemicals ${ }^{5}$. Under specified stressed conditions, a portion of the cells of Escherichia coli, the model bacterium for the study the of stress response, have often been found to lose their ability to grow on standard nutrient agar plates at the early or mid stationary phase $\mathrm{e}^{5,6,11}$. Such cells may be dead, or in the VBNC state ${ }^{12-14}$. Such an observation further drew the interests of the authors to examine the bacterial growth curve under cold shock state in order to detect the surviving cells. As the cells of $E$. coli are well known to respond against coldshock ${ }^{15}$, the present study was applied on to Pseudomonas strains.
Our earlier studies unraveled that Pseudomonas spp. had been incapable of colony forming ability on the agar plates when exposed to oxidative stress which is often related to the raise of temperature ${ }^{11,16}$. The impacts of heat shock on bacterial species have been extensively studied revealing unfolded/ denatured proteins; the studies on the effect of cold shock apparently seem to be in scarce 2, 6,7,11,15,17. However, among the environmental stresses posed on bacterial population, the theme of cold shock is not that new too ${ }^{15,18}$. A number of physiological changes especially in E. coli and Bacillus subtilis have been noted in response to a temperature downshift. The decrease in membrane fluidity, reduced efficiency of translation and transcription along with inefficient folding of some proteins and the defects in ribosomal function were demonstrated ${ }^{15}$.

One of the well-studied cold-shock response mechanisms underlies the discovery of the cold-shock proteins A (CspA) family members which are induced and function at low temperature ${ }^{19}$. Other proteins may include $\mathrm{CspB}, \mathrm{CspC}$ and $\mathrm{CspE}$ which are over expressed under cold-shock and impart the traits of motility and biofilm formation under stress ${ }^{19-22}$. The roles of RpoS and (p)ppGpp are also significant for the cold shock stress management within bacteria ${ }^{15}$.

Based on such background knowledge on cold shock response of $E$. coli and B. subtilis, present study further concentrated to observe the cold-shock response of $P$. aeruginosa, $P$. fluorescence, and $P$. putida. A preliminary growth pattern for each of the strain 
was checked first under optimal condition, and then the respective growth rates were compared when the strains were subjected to cold stress. The culturable cells, and also the possible VBNC cells of Pseudomonas spp. were estimated.

\section{Method and materials:}

Bacterial stain, medium and culture conditions for generating in vitro growth curve

Preparation of pre-cultures: Laboratory stock cultures of Pseudomonas aeruginosa, P. fluorescence, and P. putida were used in this study. Minimal agar (MA) and Luria agar (LA) were used for the assay of culturability; i.e., the formation of viable and culturable cells ${ }^{3}$. Loopful bacterial culture from each of the three different bacterial strains was introduced into respective tubes consisting of $5 \mathrm{ml}$ Luria broth (LB) and incubated at $37^{\circ} \mathrm{C}$ with shaking at $100 \mathrm{rpm}$ (rotation per minute) for 4-6 hours (preparation of pre-cultures of $P$. aeruginosa, $P$. fluorescence, and P. putida).

Preparation of main cultures: In each case, $30 \mu \mathrm{l}$ of the preculture was introduced into $30 \mathrm{ml}$ fresh $\mathrm{LB}$ and $\mathrm{MB}$ resulting in the initial $\mathrm{OD}_{600}$ (optical density or absorbance at $600 \mathrm{~nm}$ ) of the main culture 0.1 , In order to maintain the initial $\mathrm{OD}_{600}$ of the main culture around 0.1 , from $10^{-7}$ dilutions of the pre-culture, $30 \mu \mathrm{l}$ samples were transferred into $30 \mathrm{ml}$ LB followed by incubation at $37^{\circ} \mathrm{C}$ under $100 \mathrm{rpm}$; and from $10^{-3}$ dilutions $30 \mu \mathrm{l}$ samples were transferred into $30 \mathrm{ml} \mathrm{MB}$ followed by incubation at $37^{\circ} \mathrm{C}$ under $100 \mathrm{rpm}$. The main cultures were let to be incubated at $37^{\circ} \mathrm{C}$ with shaking at $100 \mathrm{rpm}$ up to 3-5 days. Assay of viable and culturable cells: At specific time intervals $(12,24$, and 36 hours, and so on) an aliquot of $1 \mathrm{ml}$ (from each of the cultures) of cell suspension was introduced into $9 \mathrm{ml}$ of LB, and the dilutions were made up to $10^{-6}$ (for spreading onto LA and up to $10^{-3}$ (for spreading onto MA). For assaying the viable and culturable cells, $100 \mathrm{ml}$ from each of the above- mentioned dilutions was spread; i.e., $10^{-6}$ dilutions for the three strains were considered for spreading onto LA plates; and $10^{-3}$ dilutions for the three strains were considered for spreading onto MA plates. Finally the plates were incubated at $37^{\circ} \mathrm{C}$ for $12-24$ hours for counting the respective colony forming units (CFUs).

Experiments on cold-shock

As described above, for the preparation of pre-cultures of $P$. aeruginosa, P. fluorescence, and P. putida, loopful pure colony of each of the bacterial culture from their respective plates was introduced into three respective tubes consisting of $5 \mathrm{ml} \mathrm{LB}$; and was incubated at $37^{\circ} \mathrm{C}$ with shaking at $100 \mathrm{rpm}$ for $2-3$ hours till the $\mathrm{OD}_{600}$ reached to indicating the exponential phase of the cells ${ }^{7}$. Then $150 \mu \mathrm{l}$ from each of the cell suspension was added to the respective $150 \mathrm{ml} \mathrm{LB}$ and to the $150 \mathrm{ml} \mathrm{MB}$ (three sets of main culture) which were further incubated at $37^{\circ} \mathrm{C}$ with shaking at $100 \mathrm{rpm}$ for 10 hours (generating the average $\mathrm{OD}_{600}$ of 0.6 0.8 (indicating the exponential phase of the cells).
Generation of cold shock and assay of viable and culturable cells: While one set of main cultures (total 6 cultures; i.e., 10 hour cultures of $P$. aeruginosa, $P$. fluorescence, and P. putida in LB and 10 hour cultures of $P$. aeruginosa, $P$. fluorescence, and P. putida in MB) was continued incubating at $37^{\circ} \mathrm{C}$ with shaking at $100 \mathrm{rpm}$ for 3-5 days; another two sets were subjected to cold shock at $0^{\circ} \mathrm{C}$ and at $4^{\circ} \mathrm{C}$. Indeed, to generate such cold shock on the Pseudomonas cultures, aliquots of $9 \mathrm{ml}$ each from the respective 10 hour cultures ( 6 cultures; i.e., 10 hour cultures of P. aeruginosa, P. fluorescence, and P. putida in LB and 10 hour cultures of $P$. aeruginosa, P. fluorescence, and P. putida in MB) were poured onto the respective sterile cubes of ice trays. Considering two sets of low temperatures $\left(0^{\circ} \mathrm{C}\right.$ and $\left.4{ }^{\circ} \mathrm{C}\right)$, for each of the six cultures, a maximum of 8 cubes were prepared, generating a total of 96 cubes; i.e., 8 cubes (considering the viable ad culturable cell assay time intervals: $12,24,36,48,60,72,96$ and 120 hours) for each of the 3 strains in LB and in MB for keeping at $0^{\circ} \mathrm{C}$ and 8 cubes for each of the 3 strains in LB and in MB for keeping at $4^{\circ} \mathrm{C}$. For measuring the viable and culturable cells, bacterial cultures from the respective ice cubes of the marked three strains were dropped on to the LA plates (with an average amount of around $100 \mathrm{ml}$ ) followed by spreading. Plates were incubated at $37^{\circ} \mathrm{C}$ for $12-24$ hours for enumerating .

Estimation the viable but non-culturable (VBNC) cells at cold shock: Estimation of $\mathrm{VBNC}$ at $0^{\circ} \mathrm{C}$ was performed by deducting the number of culturable cells (formed as CFUs) at $0^{\circ} \mathrm{C}$ from the culturable cells (formed as CFUs) at $37^{\circ} \mathrm{C}$. Similarly the estimation of $\mathrm{VBNC}$ at $4^{\circ} \mathrm{C}$ was performed by deducting the number of culturable cells at $4^{\circ} \mathrm{C}$ from those at $37^{\circ} \mathrm{C}$.

\section{Result and Discussion}

All 3 Pseudomonas strains showed standard growth in both Luria Broth (LB) and minimal broth (MB). Among the 3 species, $P$. aeruginosa showed an apparent ideal growth curve in both minimal and Luria broths. Maximum culturable cells; i.e., around $10^{6} \mathrm{CFU} / \mathrm{ml}$ in each case appeared at $24-48$ hours, and after that a steady decline in the numbers of the culturable cells Was observed (Figure 1A-C). A reduction by an average of 1-log was noticed in case of the culturable cells from the MB compared to those from LB for all Pseudomonas species (1A-C).

Aliquots of $30 \mu 1$ of each of the pre-cultures of the 3 bacterial strains were introduced into $30 \mathrm{ml}$ fresh Luria Broth (LB, black bars) and $30 \mathrm{ml}$ Minimal Broth (MB, grey bars), followed by incubation at $37^{\circ} \mathrm{C}$ under shaking condition (at $100 \mathrm{rpm}$ ). At specific time intervals, $100 \mathrm{ml}$ from each of the respective dilutions of the main bacterial cultures were spread onto LA plates and onto the MA plates. After incubating the plates at $37^{\circ} \mathrm{C}$ for 12-24 hours, colony forming units (CFUs) were enumerated to measure the viable and culturable cells. Maximum culturable cells (around $10^{6} \mathrm{CFU} / \mathrm{ml}$ ) appeared at 24-48 hours, and after that a gradual decline in the numbers of the culturable cells were observed (1A-C). A reduction by an average of 1-log was noticed in case of the culturable cells from the MM compared to those from LB in all cases (A-C). 

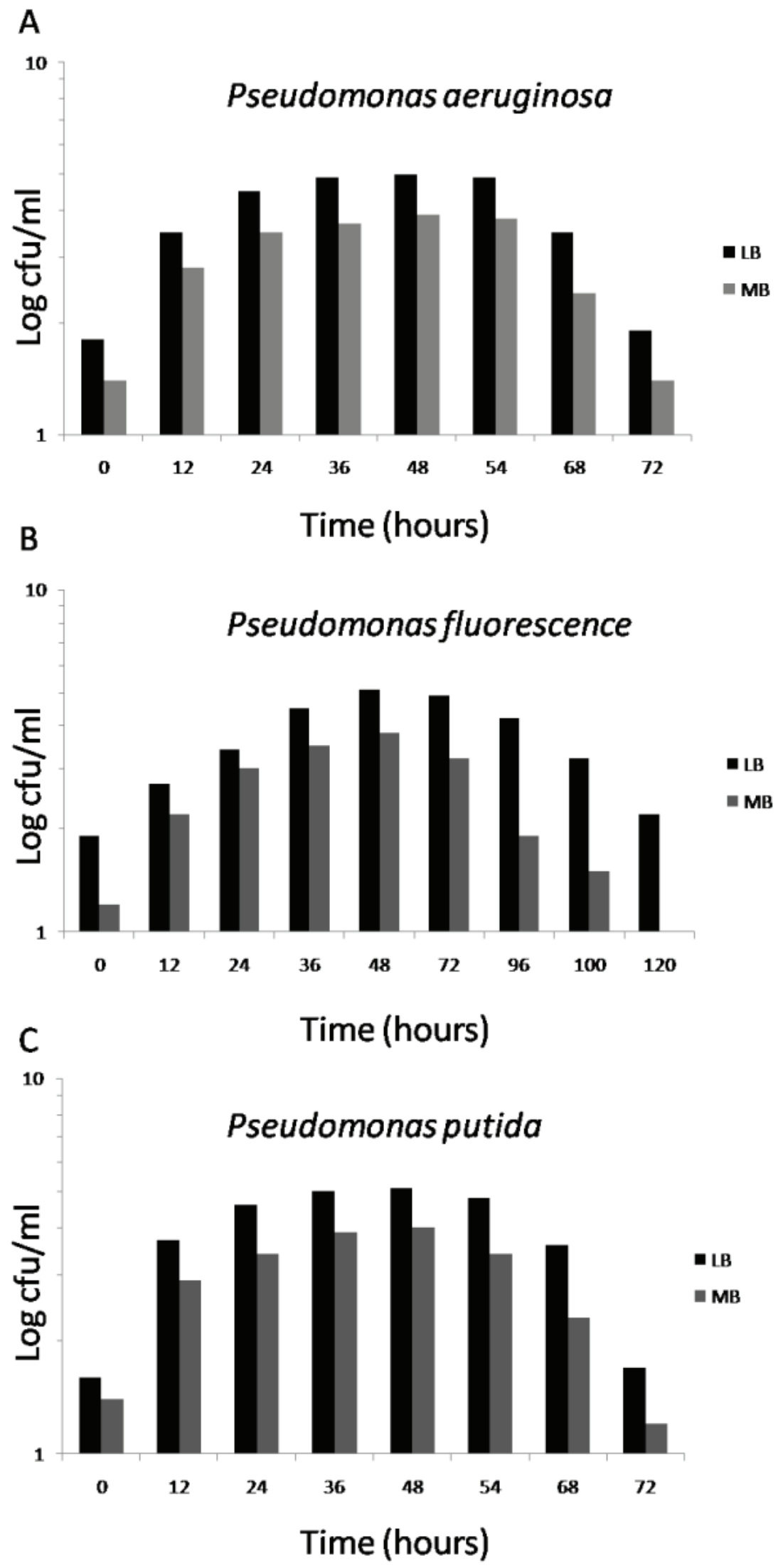

Figure 1. Assay of viable and culturable cells of A. Pseudomonas aeruginosa, B. P. fluorescence, and C. P. putida at optimal temperature. 

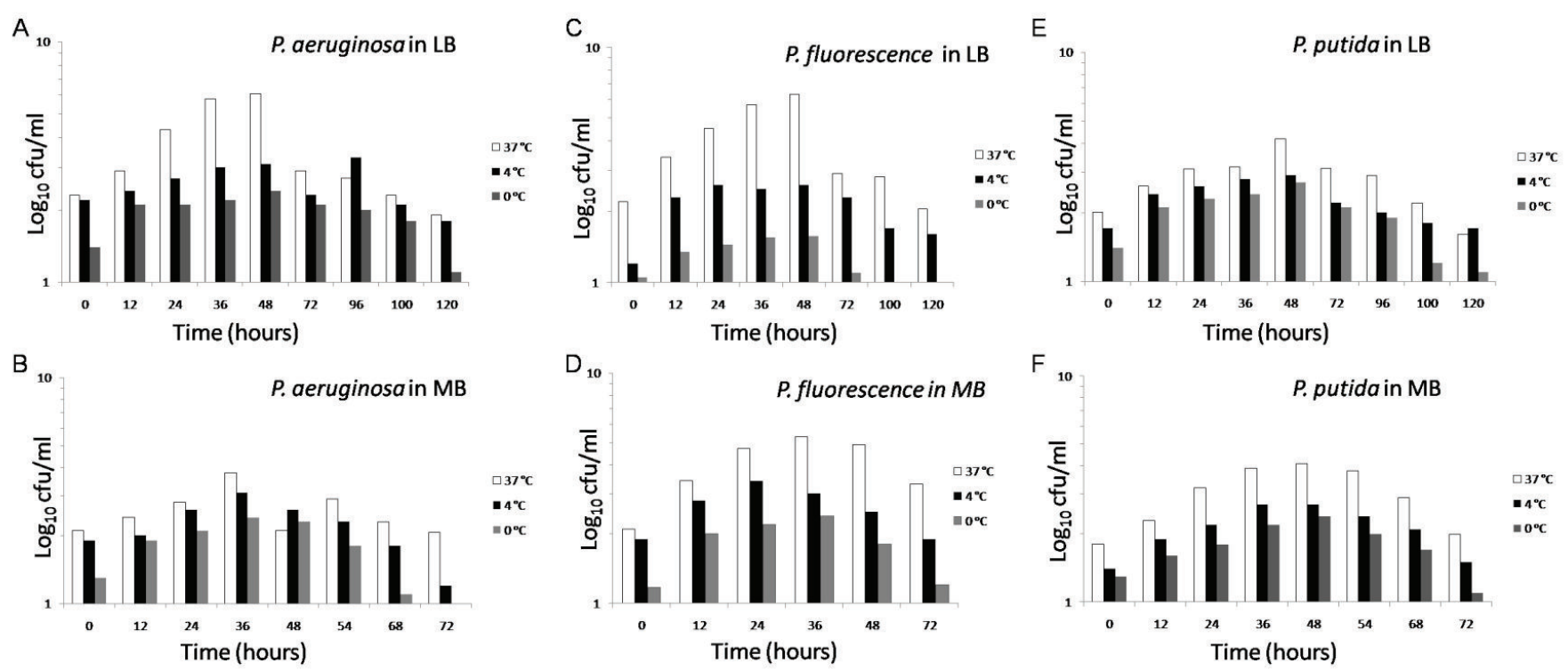

Figure 2. Assay of viable and culturable cells of A, B. Pseudomonas aeruginosa, C, D. P. fluorescence, and D, E. P. putida under cold shock in $L B(A, C, E)$ and in $M B(B, D, F)$.

Two sets of low temperatures (grey bars indicating $0^{\circ} \mathrm{C}$ and black bars indicating $4^{\circ} \mathrm{C}$ ) were considered for cold shock in comparison to normal condition (white bars indicating $37^{\circ} \mathrm{C}$ ). For the assay of the viable and culturable cells under cold shock, ice cubes of all the bacterial strains were generated, which were later used for plating for the enumeration of the colony forming units (CFUs). The reduction of culturable cells of all 3 strains was noticed under cold shock at each specific time points of assay. Estimation of viable but non-culturable cells (VBNC) at these two low temperatures $\left(0^{\circ} \mathrm{C}\right.$ and $\left.4^{\circ} \mathrm{C}\right)$ was performed by deducting the number of CFUs at $0{ }^{\circ} \mathrm{C}$ (grey bars) and $4^{\circ} \mathrm{C}$ (black bars) from the CFUs formed at $37^{\circ} \mathrm{C}$ (white bars). While the number of culturable cells decreased in course of time under cold shock, the number of VBNC apparently seemed to be constant.

\section{Reduction of viable and culturable cells at cold shock}

The reduction of culturable cells of all 3 strains was noticed under cold shock at each specific time points of the assay. In case of $P$. aeruginos $a$, at $0^{\circ} \mathrm{C}$ the highest reduction (5-log reduction) in the amount of the culturable cells was observed at 36 hours of growth in LB media while in MB the reduction was scored around 2-log (Figure 2A, B). At $4^{\circ} \mathrm{C}$ cold shock condition, 4-log reduction in the amount of the culturable cells was observed at 36 hours of growth in LB media while in MB the reduction was scored nearly 1-log. In case of $P$. fluorescence, at $0^{\circ} \mathrm{C}$ the highest reduction (6$\log$ reduction) of the culturable cells was observed at 36 hours in $\mathrm{LB}$ media while in MB the reduction was half. At $4^{\circ} \mathrm{C}, 2-\log$ reduction in the amount of the culturable cells was observed at 36 hours in both LB media and in MB (Figure 2C, D). In case of $P$. putida, at $0^{\circ} \mathrm{C}$ the highest reduction $(3-\log )$ in the amount of the culturable cells was observed at 36 hours of growth in $\mathrm{MB}$ while in LB the reduction was $1-\log$. At $4^{\circ} \mathrm{C}$ cold shock condition, $1-\log$ reduction in the amount of the culturable cells was observed at 36 hours of growth in LB media while in MB the reduction was scored approximately 2-log (Figure 2E, F). Comparing to the steady state growth curve at $37^{\circ} \mathrm{C}$, the culturable cells at $0^{\circ} \mathrm{C}$ and at $4^{\circ} \mathrm{C}$ were found to gradually decrease. In case of $P$. aeruginosa, no culturable cells were detectable after 68 hours. A comparatively lower number of VBNC was noticed under cold shock in case of P. putida.

Constant numbers of VBNC were noticed in P. aeruginosa at cold shock

While grown at $0^{\circ} \mathrm{C}$, although the number of VBNC (culturable cells at $37^{\circ} \mathrm{C}$ and culturable cells at cold shock) in case of both P. aeruginosa was noticed to increase within 24-48 hours during growth both in LB and (MB) (Figure $2 \mathrm{~A}, \mathrm{~B}$ ); however, that was minor and afterwards the number was decreased. While grown at $4^{\circ} \mathrm{C}$, the VBNC number seemed to be decreased than the number calculated from the growth at $0^{\circ} \mathrm{C}$. Indeed in $\mathrm{MB}, \mathrm{VBNC}$ seemed to be in a lower number than those in LB.

Increased numbers of VBNC cells were noticed in P. fluorescence at cold shock: a possible reason for better survival

In contrast to $P$. aeruginosa, higher numbers of VBNC were noticed in P. fluorescence in both $\mathrm{LB}$ and $\mathrm{MB}$ with a higher ratio of VBNC cells in the LB medium (Figure $2 \mathrm{C}, \mathrm{D}$ ). Interestingly the culturable cells in $P$. fluorescence were higher than the culturable cells of both $P$. aeruginosa and P. putida (Figure $2 \mathrm{C}$ - F). The larger number of VBNC cells in P. fluorescence than the other strains might be an evidence of survival (reflected by the ability of this strain to form culturable cells) of P. fluorescence at cold shock. The largest number of culturable cells among all 3 Pseudomonas strains was noticed in case of $P$. fluorescence while grown at cold temperatures (Figure $2 \mathrm{~A}-\mathrm{F}$ ). 
Relatively low numbers of viable and non-culturable (VBNC) cells were noticed in P. putida at cold shock

In contrast to $P$. aeruginosa and especially to $P$. fluorescence, relatively lower numbers of VBNC were noticed in $P$. putida in both LB and MB (Figure 2 E, F). In turn, the number of the culturable cells (formed as CFUs) in P. putida was found to be lower than those from $P$. aeruginosa and P. putida (Figure 2 A - D).

\section{Discussion}

Our previous studies on the VBNC formation was based on the generation of temperature stress and oxidative stress in mostly Escherichia coli, Bacillus spp., and to Pseudomonas strains to a little extent $6,7,11,16$. Results of the current study met the objective where the formation of VBNC was expected at cold temperature stress. Besides, a number of studies have been performed using cold shock on E. coli and Bacillus spp. whereas reports on the cold shock effect on Pseudomonas spp. is not that abundant ${ }^{15}$, $19,23,24,25$, Even though the current study lacks the examinations of the cold-shock genes of Pseudomonas spp.; however, the data found here clearly reveals that $P$. fluorescence cells could survive better than P. aeruginosa and than P. putida at cold temperatures as scored by their ability to form culturable cells.

E. coli cells are likely to undergo a decrease in viable cell number in the early stationary phase when grown in rich media ${ }^{26}$. In the current study a similar scenario has been noticed in case Pseudomonas strains since the growth was abundant in LB (nutrient rich medium) compared to that in MB (Figure 1A - C).

Initially, at the stationary phase, the $\mathrm{s}^{\mathrm{E}}$-dependent lysis of the dead cells and the damaged cells has been extensively observed ${ }^{26}$. Later some suggestive data clearly showed that VBNC cells may accumulate in the early clearly stationary phase in addition to those dead cells and the damaged cells due to nutrient depletion, heat shock or due to the oxidative stress ${ }^{6,7}$. Accumulation of such lysis was clearly visible as the aggregate accumulated in the culture media ${ }^{6,7,11,17,27-30}$. Interestingly, the accumulation of the aggregates has also been noticed during the current experiments when Pseudomonas spp. were grown at $37^{\circ} \mathrm{C}$ (data not shown). Such cell lysis of the defective cells; i.e., a combination of dead cells and damaged cells or the VBNC was earlier hypothesized to be nutritionally required for the maintenance of the living cell population in the prolonged stationary phase ${ }^{26}$. Thus the survival strategy drawn by the VBNC of significant a cold shock as has been demonstrated in the present study (Figure 2). Moreover, since there are corresponding genes and homologues to the rpoE gene (encoding $\mathrm{s}^{\mathrm{E}}$, systems similar to the $E$. coli $\mathrm{s}^{\mathrm{E}}$-dependent dead cell lysis may exist in many microorganisms including in Pseudomoans spp. Such system may be crucial for cell turnover in stressed growth condition as indicated as the low temperature in the current study. Perhaps the lysis of the dead cells and of the VBNC cells provided nutrients for the remaining population seen at $4^{\circ} \mathrm{C}$ an at $0^{\circ} \mathrm{C}$
(Figure 2). Further studies on such aggregate accumulation and the lysis of Pseudomoans would be interesting to decipher the mechanism of Pseudomonas response against cold shock.

\section{Conflict of interest: None}

\section{References}

1. Bren A, Hart Y, Dekel E, Koster D and Alon U. 2013. The last generation of bacterial growth in limiting nutrient. BMC Systems Biology, 7, 27. http://doi.org/10.1186/1752-0509-7-27

2. Noor R, Malek M, Rahman MS, Meghla M, Acharjee M and Rahman MM. 2015. Assessment of Survival of Pathogenic Bacteria in Raw Fresh Vegetables through in vitro Challenge Test. International Journal of Food Contamination. 2:15. DOI: 10.1186/s40550-015-0021-3

3. Noor R, Islam Z, Munshi SK and Rahman F. 2013. Influence of Temperature on Escherichia coli Growth in Different Culture Media. $J$ Pure Appl Microbiol. 7(2): 899-904.

4. Zhao X, Zhong J, Wei C, Lin CW and Ding T. 2017. Current Perspectives on Viable but Non-culturable State in Foodborne Pathogens. Frontiers in Microbiology, 8, 580. http://doi.org/10.3389/fmicb. 2017.00580

5. Noor R. 2015b. Mechanism to control the cell lysis and the cell survival strategy in stationary phase under heat stress. SpringerPlus. 4:599. DOI: 10.1186/s40064-015-1415-7.

6. Noor R, Murata M and Yamada M. 2009. Oxidative stress as a trigger for growth phase-specific s $\mathrm{s}^{\mathrm{E}}$-dependent cell lysis in Escherichia coli. J Mol Microbiol Biotechnol. 17(4):177-87.

7. Noor R, Murata M, Nagamitsu H, Klein G, Raina S and Yamada M. 2009b. Dissection of $\mathrm{s}^{\mathrm{E}}$-dependent cell lysis in Escherichia coli: roles of RpoE regulators RseA, RseB and periplasmic folding catalyst PpiD. Genes Cells. 14(7):885-99.

8. Boor KJ. 2006. Bacterial stress responses: What doesn't kill them can make them stronger. PLoS Biology 4(1): e23.

9. Nystrom T. 2005. Role of oxidative carbonylation in protein qualitycontrol and senescence. EMBO J 24: 1311-1317.

10. Nystrom T. 2003. Conditional senescence in bacteria: death of the immortals. Mol Microbiol 48: 17-23.

11. Nur IT, Munna MS and Noor R. 2014. Study of exogenous oxidative stress response in Escherichia coli, Pseudomonas spp., Bacillus spp. and Salmonella spp. Turkish Journal of Biology. 38(4): 502-509.

12. R Noor, M Murata and M Yamada. 2009. Oxidative stress as a trigger for growth phase-specific ÃE-dependent cell lysis in Escherichia coli. Journal of molecular microbiology and biotechnology. 17(4), 177-187

13. Cuny C, Dukan L, Fraysse L, Ballesteros M and Dukan S. 2005. Investigations of the first events leading to the loss of culturability during Escherichia coli starvation: future nonculturable bacteria form a subpopulation. J Bacteriol 187: 2244-2248.

14. Desnues B, Cuny C, Gregori G, Dukan S, Aguilaniu H and Nystrom T. 2003. Differential oxidative damage and expression of stress defence regulons in culturable and non-culturable Escherichia coli cells. EMBO Rep 4: 400-404.

15. Phadtare S. 2004. Recent Developments in Bacterial Cold-Shock Response Curr. Issues Mol. Biol. 6: 125-136.

16. Munna MS, Tahera J, Afrad MH, Nur IT and Noor R. 2015. Survival of Bacillus spp. SUBB01 at high temperatures and a preliminary assessment of its ability to protect heat-stressed Escherichia coli cells. BMC Res Notes. 8: 637.

17. Murata M, Noor R, Nagamitsu H, Tanaka S and Yamada M. 2012. Novel pathway directed by $\widetilde{\mathrm{A}}^{\mathrm{E}}$ to cause cell lysis in Escherichia coli. Genes Cells. 17(3): 234-47.

18. Jones PG, Inouye. 1994. The cold-shock response-a hot topic. M. Mol Microbiol. 11(5): 811-8. 
19. Michaux C, Holmqvist E, Vasicek E, Sharan M, Barquist L, Westermann AJ, Gunn JS and Vogel J. 2017. RNA target profiles direct the discovery of virulence functions for the cold-shock proteins CspC and CspE. Proc Natl Acad Sci U S A. 27;114(26): 6824-6829. doi: 10.1073/ pnas. 1620772114.

20. Shenhar Y, Biran D and Ron EZ. 2012. Resistance to environmental stress requires the RNA chaperones CspC and CspE. Environ Microbiol. Rep. 4(5): 532-9.

21. Phadtare $\mathrm{S}$ and Inouye MJ. 2001. Role of $\mathrm{CspC}$ and $\mathrm{CspE}$ in regulation of expression of RpoS and UspA, the stress response proteins in Escherichia coli. 183(4):1205-14.

22. Phadtare S and Inouye M. 1999. Sequence-selective interactions with RNA by CspB, CspC and CspE, members of the CspA family of Escherichia coli. Mol Microbiol. 33(5): 1004-14.

23. Bisht SC, Joshi GK and Mishra PK. 2014. CspA encodes a major cold shock protein in Himalayan psychrotolerant Pseudomonas strains. Interdiscip Sci. 6(2): 140-8

24. Kumar A and Khan M. 2012. Prediction of ligand binding site by insilico approach in cold resistant protein isolated from cold resistant mutant of Pseudomonas fluorescens. J Mol Graph Model. 38: 101-11.
25. Panicker G, Mojib N, Nakatsuji T, Aislabie J and Bej AK. 2009. Occurrence and distribution of capB in Antarctic microorganisms and study of its structure and regulation in the Antarctic biodegradative Pseudomonas sp. 30/3. Extremophiles. 14(2): 171-83.

26. Nitta T, Nagamitsu H, Murata M, Izu H and Yamada M. 2000. Function of the $\mathrm{s}^{\mathrm{E}}$ Regulon in Dead-Cell Lysis in Stationary-Phase Escherichia coli. Journal of Bacteriology. 182(18): 5231-5237.

27. Ayrapetyan M, Williams TC and Oliver JD. 2015. Bridging the gap between viable but non-culturable and antibiotic persistent bacteria. Trends Microbiol. 23(1): 7-13.

28. Boaretti M, Lleò MM, Bonato B, Signoretto C and Canepari P. 2003. Involvement of rpoS in the survival of Escherichia coli in the viable but non-culturable state. Environ Microbiol. 5(10): 986-96.

29. Chen L, Zhu X, Zhang M, Wang Y, Lv T, Zhang S and Yu X. 2017. Profiling Total Viable Bacteria in a Hemodialysis Water Treatment System. J Microbiol Biotechnol. 27(5): 995-1004.

30. Gumley AW and Inniss WE. 1996. Cold shock proteins and cold acclimation proteins in the psychrotrophic bacterium Pseudomonas putida Q5 and its transconjugant. Can J Microbiol. 42(8): 798-803. 